\title{
Larangan Merokok di Mata Mahasiswa: Studi Tentang Kebijakan Larangan Merokok di Tempat Umum
}

\author{
Fadhil Ilhamsyah ${ }^{1}$, Afrizal Tjoetra ${ }^{2}$, Ikhsan ${ }^{3}$ \\ ${ }^{1}$ Jurusan Ilmu Administrasi Negara, Universitas Teuku Umar, Indonesia. \\ ${ }^{2}$ Jurusan Sosiologi Universitas Teuku Umar, Indonesia. \\ ${ }^{3}$ Jurusan Ilmu Administrasi Negara, Universitas Teuku Umar, Indonesia.
}

\section{ARTICLE INFORMATION}

Received: February 04, 2020

Revised: April 24, 2020

Accepted: April 29, 2020

Available online: April 30, 2020

\section{KEYWORDS}

Student, Smoking Area

CORRESPONDENCE

Phone: +6281260313742

E-mail: ikhsan.baharudin.utu.ac.id

\section{A B S T R A C T}

This paper explains about Teuku Umar University Students' perceptions of the smoking ban policy at public places in West Aceh Regency. The smoking ban policy is an effective way of controlling smoking and indirectly reduces the negative impact on the health of passive smokers due to smoking by releasing it in public places. This research uses quantitative research methods with survey methods. the population of Teku Umar University students who accept 50 people who have an age range between 18-25 years and are male and female. The results showed that most Teuku Umar Universities were of the view that the ban on smoking in public places had run well. Even so, there are still students who do not need this policy, this can be seen from the habits of students who smoke in places that include smoking areas

\section{PENDAHULUAN}

Kebijakan yang berkaitan tentang rokok selalu diliputi oleh perdebatan yang panjang seperti merokok merupakan hak asasi manusia, berkaitan dengan persoalan ekonomi bangsa, hingga fatwa halal-haram dari Majelis Ulama Indonesia (MUI). Padahal kajian tentang rokok menujukkan bahwa kebijakan adalah cara yang paling ampuh untuk mengendalikan dan mengurangi kebiasaan merokok (Azkha, 2013). Pemerintah telah mencoba untuk menyusun berbagai peraturan dan strategi yang dapat diterapkan untuk mengatasi risiko merokok salah satunya melalui UU Kesehatan No.36 pasal 115 Tahun 2009 yaitu Larangan merokok di tempat-tempat umum seperti fasilitas kesehatan, pengasuhan anak, taman bermain untuk anak-anak, tempat ibadah, transportasi umum, tempat kerja dan area bebasrokok atau Kawasan Tanpa Rokok (KTR). Amanat UU Kesehatan ini mewajibkan setiap daerah untuk menetapkan Kawasan Tanpa Asap Rokok salah satunya adalah Kabupaten Aceh Barat dengan Peraturan Bupati Aceh Barat melalui Qanun Nomor 14 Tahun 2015 Tentang Kawasan Bebas Asap Rokok.

Beberapa kajian tentang Kawasan Tanpa Asap Rokok (KTR) mengapresiasi KTR sebagai salah satu cara yang efektif dalam mengendalikan kebiasaan merokok dan secara tidak langsung juga mengurangi dampak negatif bagi kesehatan perokok pasif akibat asap rokok (Prabandari, 2009). Namun, kebijakan ini belum sepenuhnya berjalan di Kabupaten Aceh Barat. Berbagai sebab dijabarkan dalam kajian yang lain seperti kurangnya sosialisasi, komitmen stakeholder yang setengah hati, sponsorship dan iklan yang gencar dari produsen rokok, kekurangan dana, kurang SDM, hingga minimnya partisipasi masyarakat (khususnya pemuda) dalam menyukseskan kebijakan larangan merokok di tempat umum. Hipotesis dalam penelitian tidak semua mahasiswa patuh terhadap peraturan larangan merokok di tempat umum.

Persepsi adalah proses mengatur dan memahami rangsangan yang diperoleh sehingga menjadi tugas yang terintegrasi dalam diri seseorang dan dengan persepsi manusia dapat mewaspadai keadaan lingkungan sekitar dan juga keadaan individu yang bersangkutan. (Latifah, 2015). Sedangkan pendapat berbeda diberikan oleh Matlin menggambarkan persepsi sebagai proses yang melibatkan pengetahuan sebelumnya, yang diperoleh dan ditafsirkan oleh indra. Luthans mengelompokkan faktor perhatian dalam persepsi sebagai berikut: (1) Semakin besar kekuatan rangsangan, semakin besar efeknya; (2) ukuran yaitu semakin besar objek peluang untu merasakan semakin besar; (3) kontras yaitu rangsangan dari luar berlawanan dengan latar belakang; (4) pengulangan yaitu Stimulus eksternal yang berulang dapat memperoleh paparan lebih dari sekali ; (5) gerakan yaitu orang akan memberikan atensi lebih pada objek bergerak dalam lingkungan penglihatan daripada benda tidak bergerak; (6) baru dan familiar yaitu Lebih banyak perhatian dapat ditarik ke keadaan eksternal yang baru dan akrab. Sehingga, Persepsi adalah mode penilaian satu orang dalam menghadapi rangsangan yang sama tetapi akan menyebabkan persepsi yang berbeda dalam kondisi lain. (Suprihanto, 2002).

Merokok adalah membakar tembakau dengan cara menghisap kedalam dalam tubuh dan dihembuskan kembali dan asapnya buruk bagi orang-orang di sekitarnya. Merokok adalah perilaku buruk bagi diri sendiri dan kesehatan orang lain di sekitarnya tetapi masih banyak yang melakukan aktivitas merokok (Fikriyah, 2012). Sebuah studi mengatakan bahwa kebanyakan perokok memulai kebiasaannya di usia yang sangat belia yaitu 11-13 tahun. Statistik WHO juga menunjukkan bahwa jumlah perokok di seluruh dunia adalah 30\%. dan sebanyak 12,3 
\% remaja di Indonesia adalah perokok aktif (Theodorus, 1994). Berdasarkan data tersebut dapat disimpulkan bahwa kelompok muda sangat rentan dengan godaan untuk merokok namun di saat bersamaan juga belum memahami tanggung jawab sebagai seorang perokok bagi dirinya dan lingkungan di sekitarnya (Subanada, 2008).

Beberapa sebab yang memicu keinginan merokok yaitu Setiap orang memiliki kebiasaan merokok yang berbeda dan biasanya tergantung pada tujuan mereka ketika merokok dan faktor sosio-kultural sebagai sebab seseorang merokok seperti faktor psikologis, lingkungan sosial, demografis, kondisi sosial kultural, hingga kondisi sosial politik (Sutha, 2016). Merokok menjadi sesuatu yang dipandang wajar dalam pergaulan anak muda dan biasanya kebiasaan merokok ini akan melalui tiga fase yaitu mencoba, kadang-kadang menggunakan, dan menggunakan setiap hari (Pavola, 2004).

Kebijakan adalah pilihan pemerintah untuk melakukan sesuatu atau tidak (whatever government choose to do or not to do) sehingga dengan kata lain kebijakan pemerintah dapat dikatakan sebagai kekuasaan dalam pengalokasikan nilai-nilai secara keseluruhan dan kebijakan dapat ditetapkan dengan adanya dukungan atau motivasi dari pihak yang membutuhkan dalam mengatasi masalah yang terjadi di lingkungan sosialnya. Kebijakan adalah salah satu cara efektif untuk menyelesaikan masalah. Dengan dukungan yang kuat, ini berarti para pihak tersebut benar-benar membutuhkan kebijakan itu untuk menyelesaikan masalah sosialnya (Winarno, 2012).

Kawasan tanpa rokok (KTR) adalah ruang atau area yang dianggap dilarang untuk pembuatan, penjualan, iklan, promosi dan penggunaan rokok, termasuk fasilitas kesehatan, tempat untuk belajar dan mengajar, taman bermain untuk anak-anak, tempat ibadah dan transportasi umum. Manfaat penetapan KTR yaitu upaya untuk melindungi masyarakat dari risiko bahaya kesehatan yang disebabkan oleh atmosfer yang terkontaminasi asap rokok. Penetapan Kawasan Tanpa Rokok ini perlu ditentukan di fasilitas kesehatan, tempat untuk belajar dan mengajar, taman bermain untuk anak-anak, tempat ibadah, transportasi umum, kantor, tempat-tempat umum dan tempattempat lain yang ditetapkan oleh Kemenkes RI Adapun tujuan menetapakan KTR meliputi (l) mengurangi morbiditas dan / atau mortalitas dengan mengubah perilaku hidup sehat masyarakat; (2) Meningkatkan kualitas pekerjaan secara keseluruhan; (3 Menciptakan kualitas udara yang baik dan bersih, aman dari asap rokok; (4) Mengurangi jumlah perokok dan mencegah pemula untuk merokok; (5) mewujudkan generasi muda yang sehat (Prabandari, 2009).

Kebijakan KTR adalah sarana penting untuk mengendalikan tembakau atau, lebih tepatnya, mengurangi merokok. Tobacco Control Support Center-Ikatan Ahli Kesehatan Masyarakat Indonesia (TCSC-IAKMI) bekerjasama dengan Southeast Asia Tobacco Control Alliance (SEATCA) dan World Health Organization (WHO) Indonesia melaporkan Empat alternatif kebijakan pengendalian tembakau terbaik, yaitu menaikkan pajak $(65 \%$ dari harga eceran), melarang semua jenis iklan rokok, memperkenalkan 100\% area bebas rokok di tempat umum, kantor, fasilitas pendidikan, dan peringatan merokok serta menambahkan foto pada bungkus rokok akibat kebiasaan merokok. Kebijakan KTR yang dikeluarkan oleh pemerintah daerah adalah upaya untuk memberikan perlindungan yang efektif terhadap risiko asap rokok, untuk menyediakan ruang dan atmosfer yang bersih dan sehat kepada masyarakat dan untuk melindungi kesehatan masyarakat dari dampak buruk yang dapat ditimbulkan oleh rokok dan secara tidak langsung mengurangi jumlah perokok (Azkha, 2013). Terdapat beberapa tahapan dalam pelaksanaan peraturan daerah tentang Kawasan Tanpa Rokok (KTR) diantaranya: (l) membentuk peraturan untuk pelaksanaan Perda Kawasan Tanpa Rokok (melalui Peraturan Bupati atau Peraturan Walikota); (2) Merumuskan rekomendasi dan mendistribusikannya kepada semua pemangku kepentingan dan organisasi terkait tentang adopsi dan kepatuhan peraturan nasional bebas rokok; (3) Struktur koordinasi dibentuk untuk mengimplementasikan peraturan KTR dan tim penegakan yang terdiri dari organisasi masyarakat (diprakarsai oleh Dinas Kesehatan), perguruan tinggi, organisasi keagamaan, asosiasi hotel dan restoran, asosiasi olahraga, asosiasi transportasi, entitas pemerintah, unit kepolisian dan lainnya. Fungsinya adalah agar penegakan hukum dapat berjalan dengan baik dan apabila terjadi pelanggaran dapat segera diambil tindakan.

Kebijakan tanpa merokok di Indonesia tidak pernah tercatat berhasil, yang mengakibatkan pada implementasi yang tidak serius di lapangan (bersifat sporadis dan belum menyeluruh) (Azkha, 2013). Contoh dengan ditetapkannya Kawasan Tanpa Rokok (KTR) yang diharapkan mampu mengurangi konsumsi rokok dengan cara mengendalikan kebiasaan merokok melalui pembatasan tempat yang boleh atau tidak boleh merokok (Suratman, 2011). Peraturan Bupati Aceh Barat melalui Qanun Nomor 14 Tahun 2015 tentang Kawasan Bebas Asap Rokok menunjuk sarana yang harus menerapkan KTR diantaranya institusi kesehatan, kantor-kantor pemerintah, institusi pendidikan, rumah ibadah, tempat hiburan, dan tempat bermain anak.

Pertanyaan dalam penelitian ini adalah bagaimana persepsi Mahasiswa Universitas Teuku Umar terhadap kebijakan pemerintah tentang larangan merokok di tempat umum?. Adapun tujuan penelitian ini adalah mengidentifikasi persepsi Mahasiswa Universitas Teku Umar terkait kebijakan larangan merokok di tempat umum.

\section{METODE}

Penelitiaan ini menggunakan analisis penelitian kuantitatif dengan metode survey. Penelitian survei adalah penelitian yang tidak memfokuskan perhatian pada responden dan data dikumpulkan hanya menggunakan instrumen yang telah ditentukan. Dalam penelitian survey, fokus penelitian sangat penting untuk membatasi masalah yang akan diteliti, dengan demikian, peneliti membatasi masalah untuk dianalisis hanya pada persepsi mahasiswa Universitas Teuku Umar terhadap kebijakan pemerintah tentang larangan merokok di kawasan tanpa rokok. Tujuannya agar masalah yang diteliti dapat dibatasi dan informasi yang diperoleh dapat disesuaikan dengan penelitian serta menghindari banyaknya data tidak penting yang mungkin muncul selama penelitian (Sugiyono, 2009).

Unit analisis dalam penelitian ini adalah responden yaitu responden dalam penelitian ini adalah populasi Mahasiswa Universitas Teku Umar yang berjumlah 50 orang yang memiliki rentang usia antara 18-25 tahun dan berjenis kelamin laki-laki dan perempuan. Lokasi penelitian di Universitas Teku Umar Kabupaten Aceh Barat Provinsi Aceh karena mewakili kalangan muda terdidik dalam menyikapi peraturan bupati tentang larangan merokok di tempat umum. 
Teknik pengambilan data dengan menggunakan kuisioner, studi dokumentasi melalui buku, artikel jurnal, qanun, dan dokumen pendukung lainnya. Responden yang akan diberikan kuisioner dipilih dengan cara snowball sampling terhadap mahasiswa yang berada dalam usia produktif antara 18-25 tahun dan sedang menempuh informal yaitu santri dayah/pesantren (Sugiyono, 2009).

Teknik tersebut dipilih agar responden yang diteliti benarbenar memahami dan sesuai sasaran penelitian. Kemudian teknik pengumpulan data dicapai dengan menggunakan kuesioner dalam bentuk daftar pertanyaan untuk mengumpulkan pandangan responden. Kuisioner yang lengkap menunjukkan bahwa responden hanya perlu memilih salah satu jawaban yang diberikan dengan model respons berjenjang.

Skala likert digunakan dalam penelitian ini. Oleh karena itu, pernyataan yang dibuat pada skala Likert didasarkan pada hipotesis dan indikator yang dianggap mencerminkan variabel dalam penelitian. Klasifikasi jawaban skala likert (1) sangat setuju (ss) skor 5; (2) setuju (s) skor 4; (3) ragu-ragu (r) skor3; tidak setuju (ts) skor 2; dan sangat tidak setuju (sts) skor 1.

Teknik pengolahan data dalam penelitian ini melalui tahap editing dan coding. Setelah data diperoleh, maka informasi yang diterima akan diolah dengan cara melakukan koreksi kembali (editing) atas data yang telah dikumpulkan dan selanjutnya diklasifikasi (coding) jawaban responden menurut kriteria dan ciri-ciri yang telah ditetapkan. Klasifikasi dicapai dengan menempatkan tanda kode tertentu pada setiap jawaban (biasanya angka).

Dalam melakukan analisis data, para peneliti melakukan: (1) reduksi data, yaitu pemilahan, penyederhanaan, dan abstraksi data yang dihasilkan dari kuesioner dan wawancara yang dilakukan; (2) penyajian data yaitu penyusunan data secara sistematis untuk menjelaskan masalah yang diteliti, (3) dan penarikan kesimpulan. Tujuannya agar pengujian terhadap hipotesis dapat dilakukan. Hipotesis dalam penelitian ini adalah tidak semua mahasiswa patuh terhadap peraturan larangan merokok di tempat umum.

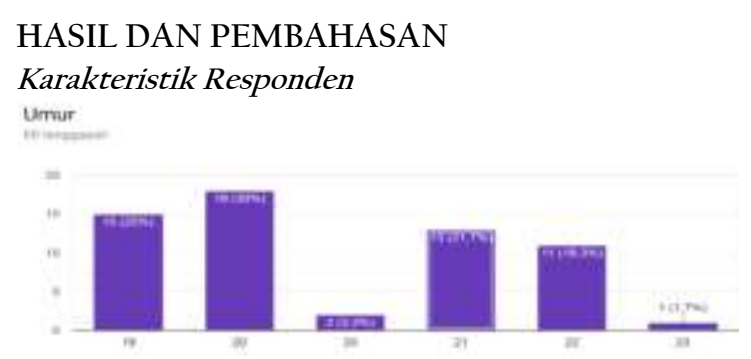

Data pada grafik di atas menunjukkan bahwa informan berjumlah 50 Orang yang terdiri dari Mahasiswa Universitas Teuku Umar Kabupaten Aceh Barat. Dari 50 Orang Responden, 18 orang (30\%) berusia 20 tahun, 15 orang ( $25 \%)$ berusia 19 tahun, 13 orang $(21,7 \%)$ berusia 21 tahun, 11 orang $(18,3 \%)$ berusia 22 tahun, 2 orang (3,3\%) berusia 20 tahun, dan 1 orang $(1,7 \%)$ berusia 23 tahun.

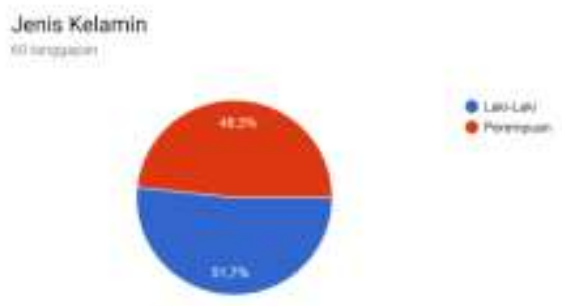

https://doi.org/10.35308/jpp.v6i1.1610
Data pada grafik di atas menunjukkan bahwa 26 orang $(51,7 \%)$ adalah laki-laki dan 24 orang $(48,3 \%)$ adalah perempuan.

Uang Bulanan Perbutar
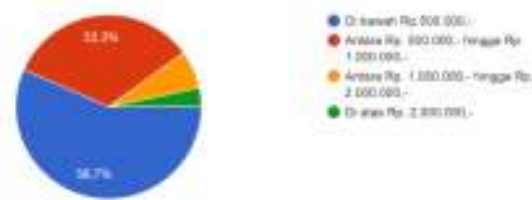

Data pada grafik di atas menunjukan bahwa 28 orang $(56,7 \%)$ memiliki uang bulanan perbulan dibawah Rp. 500.000, 17 orang $(33,3 \%)$ memiliki uang bulanan perbulan antara Rp. 500.000 hingga Rp. $1.000 .000,4$ orang (8\%) memiliki uang bulanan antara Rp. 1.000.000 hingga Rp. 2.000.000, dan 1 orang (2\%) memiliki uang bulanan perbulan diatas Rp. 2.000.000.

Persepsi Mahasiswa Universitas Teuku Umar Terhadap Kebijakan Larangan Merokok Di Tempat Umum

Agakah anda seorang perokok? Jka ya laniut ke pertanyaan bagi reponder perokok. Jika tidak lanjut ke pertanyaan bagi responden bukan perokok
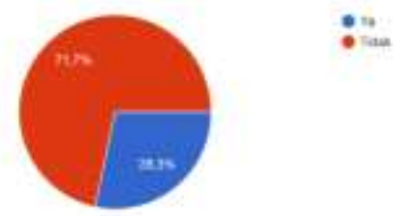

Hasil penelitian menunjukkan mayoritas Mahasiswa sebesar $71,7 \%$ tidak merokok atau bukan perokok. Hanya 28,3\% Mahasiswa yang merokok atau perokok. Hasil penelitian juga menunjukkan 83,3\% Mahasiswa yang merokok atau perokok mengetahui di mana saja kawasan yang dilarang untuk merokok, sedangkan $16,7 \%$ tidak mengetahui di mana saja kawasan yang dilarang untuk merokok sebagaimana dijelaskan pada grafik di bawah ini.

Pertanyaan bagi Perokok; Apakah anda tahu di mana saja kawasan dilarang merokak?

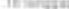

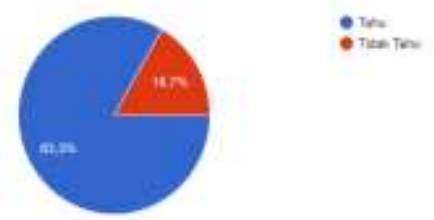

Meskipun sebahagian besar Mahasiswa mengetahui kawasan yang dilarang untuk merokok, hasil penelitian menunjukkan masih terdapat Mahasiswa yang merokok dikawasan yang dilarang. Sebagaimana dijelaskan dalam grafik dibawah ini, 93,8\% Santri Dayah terbiasa merokok di rumah makan, kafe atau kantin dan 1,7\% lainnya merokok di rumah, rumah sakit, pasar dan tempat lainnya. Tempat-tempat seperti itu sebenarnya adalah tempat-tempat di mana merokok dilarang.

\section{Pertanyaan bagi Perokok: Dimana biasanya anda merokok?}

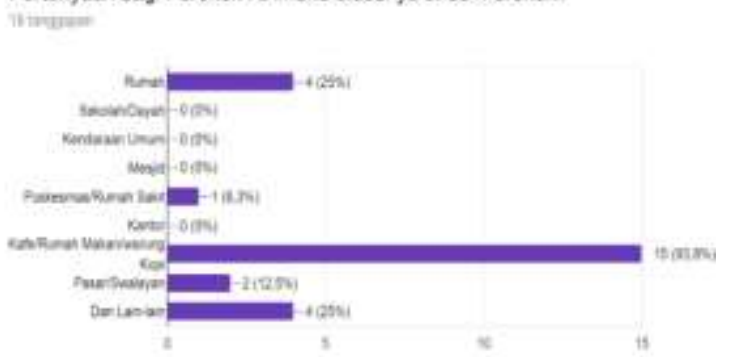


Apakah anda pernah mendengat peraturan bupat tentang larangan merokok di tempat umum?

is mocen:
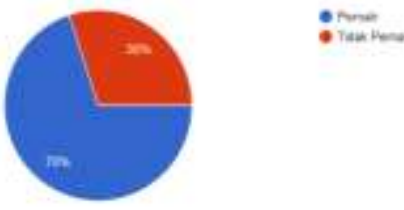

Kebiasan para Mahasiswa merokok di tempat-tempat tersebut bukan menunjukkan ketidaktahuan para Mahasiswa terhadap kebijakan kawasan larangan merokok. Hasil penelitian menunjukkan mayoritas Mahasiswa sebesar 70\% pernah mendengar kebijakan tentang larangan merokok di tempat umum. Sedangkan lainnya tidak atau belum pernah mendengar kebijakan tentang larangan merokok di area publik. Mahasiswa mendapatkan informasi tentang larangan merokok di tempattempat umum dari berbagai media sebagaimana ditunjukkan dalam grafik di bawah ini.

Jika pernah, dari mana anda pernah mendengar tentang peraturan bupat: tentang larangan merokok di tempat umum tersebut? ut lingacen

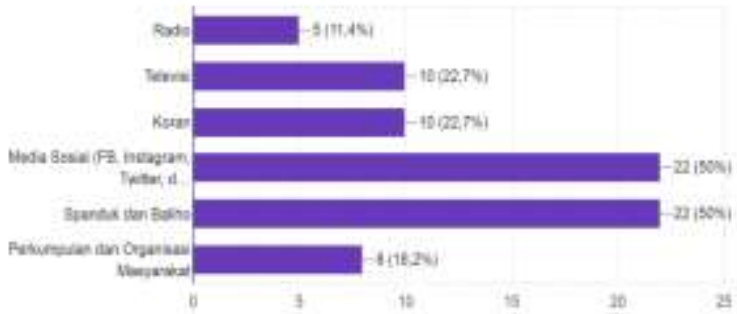

Dari grafik diatas menunjukkan bahwa $50 \%$ Mahasiswa mendengar informasi tentang kebijakan larangan merokok di tempat umum dari media sosial (Facebook, Instagram, Twitter, dan media sosial lainnya) serta spanduk dan baliho, $50 \%$ lainnya dari perkumpulan dan organisasi masyarakat, dan media lainnya (Televisi, Radio dan Koran).

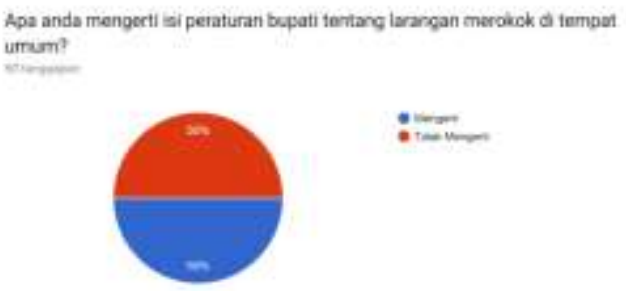

Bila dilihat dari persentase memperoleh informasi tentang kebijakan larangan merokok di tempat umum yang mencapai 70 $\%$. Akan tetapi tidak semua Mahasiswa mengerti tentang kebijakan tersebut. Berdasarkan hasil penelitian menunjukkan $50 \%$ Mahasiswa mengerti dan memahami tentang larangan merokok di tempat umum dan $50 \%$ Mahasiswa tidak mengerti tentang larangan merokok di tempat umum. Namun demikian, $90 \%$ Mahasiswa dapat menerima pemberlakuan kebijakan tentang larangan merokok di tempat umum dan hanya $10 \%$ yang tidak dapat menerima permberlakuan kebijakan tersebut sebagaimana dijelaskan dalam grafik dibawah ini.

Apakah anda dapat menerima pemberlakuan peraturan bupati tentang larangan merokok di tempat umum?
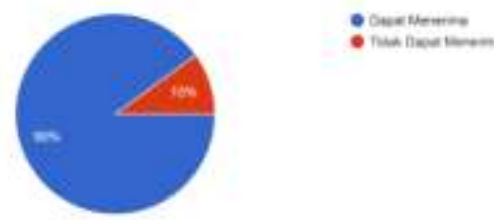

Menurut anda bagaimana penerapan Peraturan Bupati tentang larangan metokok di tempat imiam tersebut?
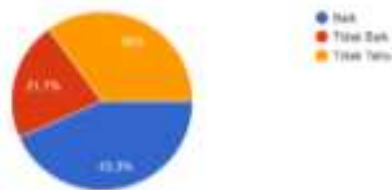

Secara umum, hasil penelitian menunjukkan mayoritas Mahasiswa sebesar 43,3\% berpandangan penerapan kebijakan larangan merokok di tempat umum telah berjalan dengan baik. Sedangkan $35 \%$ Mahasiswa tidak tahu tentang penerapan kebijakan tersebut dan 21,7 \% lainnya berpandangan penerapan kebijakan larangan merokok di tempat umum tidak berjalan dengan baik.

\section{KESIMPULAN}

Berdasarkan hasil penelitian, dapat disimpulkan bahwa mayoritas mahasiswa di Universitas Teuku Umar berpendapat bahwa kebijakan larangan merokok di tempat umum telah berjalan dengan baik. Meskipun demikian, masih terdapat Mahasiswa yang tidak mematuhi kebijakan tersebut, ini terlihat dari kebiasaan Mahasiswa yang merokok pada tempat-tempat yang termasuk kawasan dilarang merokok

\section{REFERENSI}

Azkha, N. (2013). Studi Efektivitas Penerapan Perda Kota Tentang Kawasan Tanpa Rokok (KTR) Dalam Upaya Menurunkan Perokok Aktif di Sumatera Barat Tahun 2013. Jurnal Kebijakan Kesehatan Indonesia, 2(4), 171179.https://doi.org/10.22146/jkki.v2i4.3201

Fikriyah, S. dkk. (2012). Faktor-Faktor yang Mempengaruhi Perilaku Merokok Pada Mahasiswa Lak-Laki Di Asrama Putra. Jurnal STIKES, 5(1), 99-109.

Latifah, D. (2015). Perilaku Meroko dengan Kejadian Stroke. The SUN, 2(2), 61-64.

Pavola, M. \& V. (2004). Smoking From Adolescence to Adulthood the Effect of Parental and Own Social Economic Status. European Journal of Public Health, 14(4), 417-420.

Prabandari, Y. (2009). Kawasan Tanpa Rokok Sebagai Alternatif Pengendalian Tembakau Studi Efektivitas Penerapan Kebijakan Kampus Bebas Asap Rokok Terhadap Status dan Perilaku Merokok Mahasiswa Di Fakultas Kedokteran UGM Yogyakarta. Jurnal Manajemen Pelayanan Kesehatan, 12(4), 218-225.

Subanada, I. B. (2008). Tumbuh Kembang remaja dan Permasalahannya. Sagung Seto.

Sugiyono. (2009). Metode Penelitian Kuantitatif, Kualitatif dan R\&DD. In Alfabeta.

Suprihanto. (2002). Penelitian Kinerja dan Pengembangan Karyawan. Yayasan Masa Kini.

Suratman. (2011). Gambaran Pemahaman Mahasiswa Terhadap Kebiasaan Merokok Serta Bahayanya Bagi Kesehatan Masyarakat Dan Kesehatan Lingkungan. Kesmas Indonesia, 4(1), 11-23.

Sutha, D. W. (2016). Analisis Lingkungan Sosial Terhadap Perilaku Merokok Remaja di Kecamatan Pangarengan Kabupaten Sampang Madura. Jurnal Manajemen Kesehatan Yayasan Rs. Dr.Soetome, 2(1), 43-59. https://doi.org/http://dx.doi.org/10.29241/jmk.v2il.50

Theodorus. (1994). Ciri Perokok di Kalangan Mahasiswa. Jurnal JEN, 1(3), 19-24.

Winarno. (2012). Kebijakan Publik Teori, Prose, dan Studi Kasus. CAPS. 